Maur, W. in der, Walbeek, W. van, Batenburg, R. A framework for integrating IT governance and business/lF alignment principles. International Journal of Business Innovation and Research: 2009, 3(5), 555-573

\begin{tabular}{|l|l|}
\hline $\begin{array}{l}\text { Postprint } \\
\text { Version }\end{array}$ & 1.0 \\
\hline Journal website & http://www.inderscience.com/offer.php?id=27177 \\
\hline Pubmed link & \\
\hline DOI & \\
\hline
\end{tabular}

This is a NIVEL certified Post Print, more info at http://www.nivel.eu

\title{
A framework for integrating IT governance and business/IT alignment principles
}

\author{
WESLEY IN DER MAUR, WOUTER VAN WALBEEK AND RONALD BATENBURG
}

\begin{abstract}
:
Highly information-intensive organisations such as retail banks continuously struggle with the key issues of controlling their IT-value and achieving business-IT alignment. One main reason might be that decision makers in retail banks do not use methods to plan or improve their business-IT alignment. This study provides such a method, combining principles of two well known concepts: IT governance and strategic alignment. The developed framework provides an allocation scheme for dividing strategic IT decisions between the business and IT domain by describing practical concepts to tackle the business-IT alignment enigma. The framework is validated by interviewing a number of experts from Dutch retail banks that are strongly challenged to optimise their IT value through business-IT alignment. The validation study largely supports the applicability of the framework. Furthermore, this study provides a window of opportunities to apply it to other industries, countries or specific IS/IT applications.
\end{abstract}

\section{INTRODUCTION}

Many organisations still struggle to obtain a clear view of the added value from their Information Technology and Information Systems (IS/IT). This has led to critical and popular titles in business literature such as the 'IT productivity paradox' (cf. Solow, 1987) and 'IT doesn't matter' (Carr, 2003). Within the context of this debate, the importance of aligning the organisation's IS/IT with its business domain has been recognised as critical for some time. It is usually referred to as strategic alignment or more specifically as business/IT alignment (Henderson and Venkatraman, 1993; Luftman, 1996; Kearns and Lederer, 2000; Reich and Benbasat, 2000; Chan, 2002; Luftman and Kempaiah, 2007). It is claimed that companies that achieved business/IT alignment have built strategic competitive advantage, increased visibility, efficiency, and profitability. In a similar vein, it is stated that business/IT alignment enables organisations to compete in today's changing markets (Faltermayer, 1994; Luftman and Brier, 1999; Chan, 2002; Bergeron, Raymond and Rivard, 2004; González-Benito, 2007; Kearns and Sabherwal, 2007).

The question remains, however, how business and IT can be aligned to 'answer' business demands in such a way that it is actually contributing to building a competitive advantage (Kearns and Lederer, 2000; Pandya and Anand, 2008). The challenge on how to achieve business/IT alignment is particularly applicable to the financial sector (Wilson, 1989; Barua, Kriebel and Mukhopadhyay, 1991). By using IT as a tool to discern customers' changing wants and needs and moreover, to adapt to those changes, firms tend to be successful in improving customer satisfaction (Smith, 2009). With the application of new and improved technologies banks expect to reduce costs over time and better serve their customers. Considering their high dependency on IT to support its core processes (Porter and Miller, 1985; Jarvenpaa and Ives, 1990) IT shapes the ways in which banks carry out their operations (Beccalli, 2007). Because of their high IT dependency banks were among the first to be affected by discrepancies between business and IT, in particular when the environment is rapidly changing (De Haes and Van Grembergen, 2005). In practice, 
Maur, W. in der, Walbeek, W. van, Batenburg, R. A framework for integrating IT governance and business/lF alignment principles. International Journal of Business Innovation and Research: 2009, 3(5), 555-573

financial service organisations fail to have a practical method or framework that can support decision makers with concepts on how to become aligned (Pandya and Anand, 2008).

In this article, we depart from the principle of strategic (business/IT) alignment and combine it with IT governance principles. This combination is elaborated and anchored in a new framework that can help organisations in their strategic decision making to align business and IT. A number of (Dutch) retail banking organisations will serve as validation cases for this framework. We encompass an attempt to make the business/IT alignment concept more tangible and to develop a practical tool for IS/IT management as well. The research goal of this article is twofold:

1. To develop a theoretical framework that combines IT governance and strategic alignment principles to enhance business IT alignment.

2. To apply and validate this framework specifically for retail banks by consulting experts from both the business and IT domain in these organisations.

This article is structured as follows. In the next two sections we first provide a literature review and then outline the key principles of business/IT alignment and IT governance.

These principles are conceptually combined into a framework that can support organisations in allocating strategic decision making responsibilities between the business and IT domain. Subsequently, the methodology and expert validation of this framework is presented. Based on the validation results, we close with conclusions, discussion and suggestions for further research.

\section{RELATED WORK: A LITERATURE REVIEW ON BUSINESS/IT ALIGNMENT}

In the past decade, a considerable stream of research has emerged on the domain of IT and business/IT alignment. The annotated bibliography by Chan and Reich (2007) presents over 150 articles from a literature review of 'many influential articles on information technology alignment' (p. 316). From this overview, an increasing number of articles can be extracted that has empirically investigated the impact of IT business alignment on firm performance (e.g. Papp, 1999; Kearns and Lederer, 2001; Choe, 2003; Bergeron, Raymond and Rivard, 2004; Wagner and Weitzel, 2006; Byrd, Lewis and Bryan, 2006; González-Benito, 2007; Kearns and Sabherwal, 2007; Batenburg and Versendaal, 2008). In most studies it is confirmed that firms with high alignment are superior in their performance when compared to firms with low strategic alignment (e.g. Oh and Pinsonneault, 2007). Specifically, it is found that business/IT alignment leads to a more focused and strategic use of IT which, in turn, leads to increased performance (e.g. Chan, Sabherwal and Thatcher, 2006; González-Benito, 2007).

The way business/IT alignment is conceptualised and measured differs within this stream of research. In some studies, alignment is interpreted as the levelling of maturity in the business and IT domain. In other cases, alignment addresses the communication and mutual understanding between IT and business managers. Alignment is also considered as the match between the type of IS/IT and the structure or culture of an organisation. Or, more specifically, alignment is defined as the mutual shaping of business strategy and IT strategy. Despite these differences, the Strategic Alignment Model (SAM) as introduced by Henderson and Venkatraman in 1993 serves in many cases as the conceptual starting point. We refer to (and also build upon) the work of Henders on and Venkatraman in the next section.

Given the many empirical studies, it might appear as remarkable that business/IT alignment still appears as a top concern for IT practitioners and company executives (Luftman and Kempaiah, 2007). On the other hand, overseeing the literature also shows that the empirical and conceptual work on business/IT alignment has at least two omissions. First, practical frameworks, roadmaps or development programs are often not derived from the studies. As argued in general by Pandya and Anand (2008), there is a lack of 'established innovation frameworks and models' that are 'essential for achieving desired success'. Second, the business/IT alignment studies often remain at the conceptual stage, particularly with regard to the application and development of IS/IT.

Through trends as business process management (BPM), enterprise application integration (EAI) and business process outsourcing (BPO), the process of assigning decision rights and accountabilities for IT resources within organisations has become critical. With the delegation of activities to IT suppliers (both internally as externally), IT management and IT governance has become both more strategic and complex.

This part of the business/IT alignment concept seems underestimated and underdeveloped (cf. Beukers et al., 2006). Both omissions are further addressed in the next sections of this article.

Finally, if we focus on the sectors that are covered by the (empirical) IT alignment studies, it is striking that most research has been executed before 2000 (i.e. Floyd and Woolridge, 1990; Broadbent and Weill, 
Maur, W. in der, Walbeek, W. van, Batenburg, R. A framework for integrating IT governance and business/l alignment principles. International Journal of Business Innovation and Research: 2009, 3(5), 555-573

1993; Baets, 1996; Dutta, 1996; Johnston and Yetton, 1996; Gupta, Karimi and Somers, 1997). More recently, the studies of Pollalis (2003) and Wagner (2008) can be mentioned. Based on data from 183 banks, Pollalis confirmed the general notion that banks with 'consistent strategic alignment levels' outperform other banks. He also found that the success of a banks' outsourcing policy is dependent on the consistency between its IT integration and IT-based functional coordination. Wagner looked at IT business alignment at the process level of 136 German banks. He confirmed the hypothesis that alignment improves process performance, but this effect is significantly intermediated by IS usage and IT personnel flexibility.

Based on this (condensed) literature overview, we believe that further progress can be made in the field of business/IT alignment by theoretically explicating the role of IT governance, and practically studying the IT decision making within retail banks as a highly relevant but recently under-explored sector.

\section{BUILDING AN INTEGRATIVE FRAMEWORK BASED ON STRATEGIC ALIGNMENT AND IT GOVERNANCE}

\subsection{The strategic alignment perspective}

As noted in the previous section - and quite clearly illustrated by the bibliography of Chan and Reich (2007) - the SAM of Henderson and Venkatraman (1993) is undoubtedly the most cited concept in the field of (business/)IT alignment (cf. Sledgianowski and Luftman, 2005). They originally defined the interrelationship between business and IT in two linkages: strategic fit and functional integration. We see that the model consists of four quadrants (see Figure 1). Each of these quadrants consists of four components touched upon by the alignment process. These quadrants are interrelated in several ways, illustrated by paths. Each path describes a perspective that addresses the two linkages (strategic fit and functional integration) to obtain business IT alignment throughout the organisation.

\section{[FIGURE 1]}

The strategic perspectives - as described by Henderson and Venkatraman (1993), Luftman et al. (1995) and Papp $(1995,1998)$ - are seen as means to reach alignment by effecting a change in one of the domains of business strategy or IT infrastructure and processes, through the other domains of the SAM. This change is reached through the use of three of the four domains. Plans and actions based on these perspectives should envision strategic alignment by applying the 'one that fits best' of the four perspectives, each with its own starting point (anchor), mean (pivot) and effect domain (target) (Coleman and Papp, 2006). These perspectives differ by the path they 'walk' over the alignment model. The strengths, weaknesses, opportunities and threats that surround and/or characterise the organisation, imply the chosen anchor, pivot and effect area, its vision and strategy. Henderson and Venkatraman (1993) stress that neither of these perspectives is superior to one another: 'If they were, it would not be strategic because all

firms would adopt it' (p.482). The key in really creating a competitive advantage therefore lies in choosing the right perspective for the right situation. Henderson and Venkatraman also describe in their article (1993, p. 480) that: "future challenges deal with the selection of appropriate alignment perspectives (out of the four dominant ones (...)) that best suits the business conditions and organisational objectives".

Henderson and Venkatraman (1993) describe the role of the business and IT, the driver and the performance criteria from four perspectives as the differentiating characteristics.

Those characteristics determine which perspective enables strategic alignment in a certain situation. The first perspective depicted as path ' 1 ' in Figure 1 is the strategy execution perspective. This perspectives sees the business strategy as the driver for organisational and IT infrastructural choices. This perspective is commonly used, and perceives the role of top management (business) as the strategy formulator and IT management's role is that of strategy implementer. This perspective measures its IT function through financial performances and sees it as a cost/service centre. If we plot the perspective over the alignment model, we see that it starts at a business strategic level and therefore the quadrant business strategy is the anchor point. IT is merely an operational tool to support the business in this perspective, as the pivot is the organisational infrastructure and processes quadrant and the information systems infrastructure and processes is the last quadrant to consider. The business is the strategy formulator, IT implements that strategy.

IT plays a role where it simply just takes care of automating the processes from the business side on an operational level. Their performance is measured on a cost/service centre basis. The main orientation in this perspective is on integration and therefore on operational alignment. 
Maur, W. in der, Walbeek, W. van, Batenburg, R. A framework for integrating IT governance and business/lF alignment principles. International Journal of Business Innovation and Research: 2009, 3(5), 555-573

The second perspective (path '2' in Figure 1), called technology potential describes the implementation of the business strategy through the use of IT on a strategic level. The business has certain ideas and visions on how to reach their goals and is therefore the driver for alignment. With the aid of IT on a strategic level, it aims to change the IT infrastructure and processes to be organised accordingly (on an operational level). An organisation that follows this perspective seeks for best possible IT competencies outside the usually chosen paths to fulfil customer demands. This perspective uses IT to aid the business in formulating and designing the IT infrastructure based on a top management technology vision on doing business. It measures performance based on technology leadership through which it differentiates between its competitors and gains a competitive advantage. IT is seen as imperative to operate and support the business, but the business is still leading on a strategic level.

Competitive potential is the third perspective (path ' 3 ' in Figure 1). The business views upon IT as a catalyst in changing the organisation. To change the business on an operational level, both IT and business processes are considered. This perspective allows IT to change the business based on new technologies and opportunities. However, the business still decides which technologies to implement on an operational level and therefore business leadership is measured to see whether new technologies are interesting enough to implement. Orientation is on the strategic level while IT is considered as a driver.

The fourth and last perspective (path '4' in Figure 1) describes service levels to reach a world class IT service organisation. This perspective is called the Service Level

perspective. A thorough knowledge, implementation and fit of the external dimensions with the IT strategy and a corresponding internal design of the IT infrastructure and processes are needed. This fit will allow the business to meet complex customer demands and to use technological advancements. The business merely prioritises the processes; the business strategy drive is indirect. There is a strong influence of IT as a driver for operational success to meet customer demands. Performance criteria are measured through customer satisfaction.

To summarise, the four perspectives suggest four different routes or paths to achieve alignment between business and IT. Based on these paths, the strategic level is connected to the operational level in order to reach strategic alignment by a functional and integral

fit. Secondly, the four routes sketch the way to combine the business and IT domain in order to reach strategic alignment by functional integration.

\subsection{The IT governance perspective}

During the last decade, both practitioners and scholars have developed increasing interest in the field of IT governance (Van Grembergen, 2000; Van Grembergen and de Haes 2004), also in relation to business/IT alignment (cf. Broadbent and Kitzis, 2005).

IT governance is about specifying the decision rights and accountability framework to encourage desirable behaviour in the use of IT (Weill and Ross, 2004; ITGI, 2006). The Cobit framework can be considered as one of the first IT governance frameworks (Brand, 2007). IT governance actually determines the benefits received from IT investments.

According to Weill (2004), organisations that outperform their competitors in profiting from IT investments particularly:

1. clarify their business strategies and the role of IT in those strategies to reach them

2. manage IT on cost and received value

3. design organisational practices to fit IT to their business needs

4. assign responsibilities to the organisational changes required to benefit from IT

5. learn from each implementation in the past, allowing them to become a networked and mature organisation.

\section{[TABLE 1]}

Weill and Ross (2004) captured IT governance decisions into a model, the 'governance arrangement matrix'. This matrix is built on five terms concerning decisions that apply to IT governance:

1. IT principles

2. IT architecture

3. IT infrastructure

4. the business applications needs

5. IT investment and prioritisation. 
Maur, W. in der, Walbeek, W. van, Batenburg, R. A framework for integrating IT governance and business/lF alignment principles. International Journal of Business Innovation and Research: 2009, 3(5), 555-573

Table 1 below provides an overview and description on what these decisions entail. The labels of the decisions are based on the work of Weill and Ross (2004), while we extended their descriptions with the work of other scholars.

\subsection{Combining strategic alignment and IT governance: the integrative framework}

In this section, a framework is constructed to define the playing field of ways to achieve business/IT alignment. The framework is driven by the notion that organisations will envision different perspectives to interpret and align their business and IT and to sustain this alignment in the future. Based on the characteristics of a certain perspective, organisations can make a proposition on where the locus of decision is to be placed when considering the IT governance decisions and what role IT and the business need to play.

Below, the strategic IT governance decisions as developed by Weill and Ross will be linked with the four strategic alignment perspectives by Henderson and Venkatraman.

We performed a theoretical exercise, by arguing what the consequences are of applying each of the four alignment perspectives for the positioning of the IT governance decisions. Recall that we derive generic expectations in this way, which are not validated yet. This will be the subject of section 3 .

1. IT governance from the service level perspective - concerning the service level perspective, we see that IT is the driver to improve customer satisfaction. This perspective sees the role of the business strategy as indirect and is necessary to ensure the effective use of IT resources and to be responsive to the growing and fast-changing demands of the end-user population (Henderson and Venkatraman 1993). Once related to the IT decisions it is proposed that IT principles are driven by IT due to their role as executive leader. The business totally relies on IT to answer customer demands and allows IT to fully decide on most of the decisions except for investments and prioritisation as they are the prioritiser.

2. IT governance from the competitive potential perspective - this perspective has a strong IT character. IT is the driver to exploit emerging IT capabilities to impact new products and services. It allows for strategic change in the business. IT is therefore heavily intertwined in the organisation and acts as a catalyst for change. We see that the business is sharing its decision on IT principles. The business is supplying business requirements but has IT to find solutions. The investments and prioritisation decision is still in the hands of the business as they act as business visionaries supporting the change IT can have. The business sees IT as an strategic asset in gaining business leadership and is deciding on approving and implementing the proposed emerging technologies and designs for the organisational infrastructure and processes.

3. IT governance from the technology potential perspective - technology potential has a strong strategic orientation to use IT to redesign their IT organisation design. The business is still leading, as their strategy is the driver in this perspective. But the business relies heavily on IT and its capabilities to create technology leadership by designing (a) competitive IT infrastructure and processes. Through the elicitation of an IT strategy that's strongly linked with the business strategy at a strategic level, it will change the IT infrastructure and processes at the operational level. IT principles are therefore formulated by the business, together with IT. Through the elicitation and influence of an IT strategy on the organisation's processes (as well as IT's role as technical architect) IT decides on architecture decisions. Considering IT infrastructure, it is IT that decides, as this decision is too technical for the business to decide upon. IT and the business together also become the decision makers within the business application needs. This is because the business is interested in IT to 'enable' the business strategy. IT has to report and negotiate to/with the business to prioritise and confirm IT investments.

4. IT governance from the strategy execution perspective - strategy execution has a firm operational orientation on alignment. Since the business is formulating the strategy and is changing the business' operational side, it is the business making almost all decisions. IT has a role as a strategy implementer on an operational level. The IT investments and prioritisation are formulated by the business as it is a strategic decision and describes how IT will be used in future plans. The decision then drills down into the entire organisation and accompanying decisions. IT architecture describes the enterprise wide standardisation and process integration on an operational level. Along the path this perspective implies, it is seen that business process are altered by the business strategy. Making the business, the decision maker here. IT infrastructure is a typical technological decision that is made by IT to be able to implement and automate business processes. IT's main 
Maur, W. in der, Walbeek, W. van, Batenburg, R. A framework for integrating IT governance and business/lF alignment principles. International Journal of Business Innovation and Research: 2009, 3(5), 555-573

purpose is to implement business processes in systems and not to interfere with the business on a strategic level or to change the organisational design. Business application needs decisions are also taken by the business, as they decide what is needed from applications, while IT will implement these.

Now that we have conceptually mapped IT governance decisions for each of the strategic alignment perspectives, we can summarise this by the following framework - depicted by Figure 2. For each of the four perspectives it specifies which decision is allocated to the business domain, the IT domain, or both (the business/IT domain).

\section{[FIGURE 2]}

\section{RESEARCH METHODOLOGY}

For this study, interviews with experts from the (Dutch) retail bank sector were organised to validate the framework. We developed an interview protocol that was focused on exploring the completeness, correctness and consistency of the structure and assumed decisions of our framework. Face to face interviews were held in a semi-structured way. Semi-structured interviews are commonly used to collect qualitative data in a case study stetting (Kvale, 1996). This technique is prepared by arranging a situation (i.e. the frameworks and its elements) that allows a respondent the time and scope to talk about their opinions on a particular subject. As the main objective was to retrieve and understand the respondents' individual point of view with regard to the validity and applicability of the framework, personal in-depth interviewing is a preferred method over other techniques as a survey or group/workshop meeting. We follow Kvale (1996) and other scholars (e.g. Yin, 2002) that interviewing is the preferred method when 'how' or 'why' questions are being posed to the respondent in a managerial setting with qualitative topics.

Open ended questions were handed to the respondent by the interviewer. Along the interview, some questions were added on an ad hoc basis and some questions were not exactly the same for all respondents. An interview protocol and short briefings before and after the interviews were used to track the subjects that were discussed during the interviews. These themes directly link to the framework. The retrieved data were then transcribed (for every interview a transcript report was made) and verified by the respondents. Finally, the transcripts were tagged according to the themes for this study, resulting in a database containing citations, statements and ideas uttered by the interviewees labelled or ('tagged') with categories and subjects (cf. qualitative coding, Miles and Huberman, 1994).

The respondents for expert validation were selected based on their expertise, background, position and interests in the Dutch retail sector. As a main stratification criterion, it was assured that professionals from all large retail banks in the Netherlands as well as chairmen of national knowledge groups were interviewed. All interviewees are able to provide input, i.e. data to answer the research question based on their experience.

An overview of interviewees is presented in Table 2 below.

\section{[TABLE 2]}

\section{ANALYSIS AND RESULTS}

The experts were asked to think through the IT governance decisions by presenting the four strategic alignment perspectives as differing scenarios. In this way, they were challenged to envision such a situation and elaborate on strategic and tactical steps they would take to cope and/or profit from that situation.

\subsection{Validation of the service level perspective on IT governance}

In our framework, we expect that IT has a strong influence on the IT decisions and the IT strategy considering the capabilities offered by IT to change the business. IT is therefore strategically used to answer customer demand. In the case of banks, we expect that banks answers this demand in a more effective and better way than its competitors, by creating strategies that aim at extracting knowledge and using services from external parties (such as sourcing processes) as tendering and payments.

\subsubsection{Interview results}


Maur, W. in der, Walbeek, W. van, Batenburg, R. A framework for integrating IT governance and business/lF alignment principles. International Journal of Business Innovation and Research: 2009, 3(5), 555-573

To achieve alignment in the service level perspective, the proposed allocation is not fully answering the business' needs. They want the business to be of more important. The conceptual model solely proposed a prioritising task for the business. But the business will also decide on the IT principles to stay in control. A respondent stated the following, which underlines the above: "What is needed, are a couple of so called 'visionaries' that start thinking on long term plans. The business formulates what it needs from IT and how they see its place in the organisation. IT will focus stronger on technical aspects inline with that proposed vision of the business" (Business manager).

The service level perspective allocated IT principles and IT business application needs decisions to IT, to enable a fully IT driven organisation. Moreover, a thorough need for IT knowledge on the external domains is needed to meet complex customer demands.

Yet, organisations generally chose the business above IT for these decisions. Strategic decisions are generally kept at the business side to ensure market responsiveness and avoid technology pushes by IT.

Although IT is not in control of these strategic decisions, IT does operate as an advisor or partner to the business in the strategy process. IT should focus on the IT architecture and the shared business application needs decision. The IT architecture will enable the interface-ability with the service providers. One of the respondents illustrated this by mentioning that: "The increasing number of IT possibilities will account for a new way of interpreting IT then is currently being done by the business. Let IT look for possibilities and allow for rigorous changes in the process and data integration. The business is increasingly starting to understand that it should heavily invest in IT to adhere to both internal and external (customer) demand.

In the end, this will provide enormous advantages to the organisation as a whole' (Business manager)." The business application needs will enable the quick responsiveness to customer demand and IT should do so by positioning itself more towards the service providers (IT suppliers). This enables the fast implementation and use of IT services, which enables the business to answer the increase in demand complexity and provide flexibility and interoperability. The business task in this process is to prioritise IT projects, elicit clear rationalised business requirements, and position itself more towards the customer to know what she needs.

The roles as stated by the strategic alignment perspective are confirmed, yet to be supplemented by tasks that ensure the business' involvement in the decisions that were assigned to IT in the propositions. In this perspective, the business allows IT to change the business processes, but remains active as a business visionary, setting out strategies.

\subsection{Validation of the competitive potential perspective on IT governance}

The competitive potential perspective expects a business visionary role for the business and catalyst role for IT in an organisation, which will reach alignment by explicitly aligning the business and IT strategies to reorganise the business processes. IT and the business together decide on the role of IT in the organisation and the business requirements for business applications. IT decides on IT infrastructure and on enterprise wide standardisation and integration for IT efficiency while the business decides on investments and prioritisation in projects.

\subsubsection{Interview results}

The business feels that the organisation is business strategy driven and that the influence of the IT strategy in the decisions is minimal. Although efficiency can be supported by IT, strategy is set out by the business to avoid a technology push.

To effectively contribute to the alignment process, IT rationalises the current IT landscape by focusing on standardisation and thus the architecture decisions. At the same time, IT searches for new solutions that are bound to increase efficiency: 'It's the bank's strategy to reach higher efficiency levels than others and Information technology

provides the tools' (Business manager). IT rationalises the business' IT demands and makes them fit the standardised architecture to help facilitate this business strategy.

IT advises the business on how to use new technologies by giving extensive input to the business as a technical architect: 'Rationalization of the current IT landscape to reach

complexity reduction' (IT architect). IT then helps implementing it, while aiming for standard solutions. Architecture is a priority in this process as it enables the enterprise wide standardisation of technology, data-use, application design and management of change to exploit new technologies. This ensures "the capability to integrate services to offer multiple products to the same customer to increase the 'share of 
Maur, W. in der, Walbeek, W. van, Batenburg, R. A framework for integrating IT governance and business/lF alignment principles. International Journal of Business Innovation and Research: 2009, 3(5), 555-573

wallet'. The customer has to do more banking activities through the internet to increase efficiency and so banks 'push its customers to cheaper channels"” (IT architect).

This is of great importance as "Straight through processing becomes essential to reach the desired efficiency for business processes. IT architectures must support this." "IT therefore acts as an advisor to the business on the restrictions/threats and opportunities the IT architecture offers and what available technologies it can provide for business problems" (Business manager).

The role the business takes on to ensure alignment in above described process supports the business visionary role for the business, which lets IT inspire business strategy and eventually reorganise the operational business processes based upon IT.

"Lowering Time To Market of products enabled by IT functionalities is crucial to obtain Business IT Alignment. To lower Time To Market, a highly flexible IT controlled, but business driven architecture is required" (CEO).

\subsection{Validation of the technology potential perspective on IT governance}

In our framework, we expect that the business relies heavily on IT and its capabilities to create technology leadership by designing competitive IT infrastructure and processes.

The business and IT together decide on the role of IT in the organisation, on investments and projects prioritisation and the business requirements for business applications. IT alone decides on IT infrastructure and enterprise wide standardisation and integration.

\subsubsection{Interview results}

The technology potential perspective implies an increase in customer demand complexity, but does not entail a large increase in technology innovations. This demands a lot from banks, and banks that must react to that demand with currently available technologies. Therefore, the bank needs to find new innovative solutions to be competitive, causing a lot of non-standard requests for IT, making integration of IT difficult.

The strategic decisions (IT principles and IT investments and prioritisation) are allocated to the business. The business turns to IT to find and help to integrate new solutions, but decides on the strategic decisions on how to use IT (principles) and if and when to invest (investments and prioritisation). The organisation has to listen to its customers to design their strategies and this is done by the business as one of the respondents illustrated: "IT can't be ignored in the strategy formulation process: The credo 'you ask, we'll deliver' No longer stands. One might sooner find that the following credo holds: "If we do not deliver, you cannot run your business. IT is seen as a key enabler, but is not deciding on all of the IT aspects in the organisation to ensure market responsiveness and avoid technology pushes by IT, but should show IT advantages" (CEO).

However, the business will accept input from IT to enable answering the demand from customers. The business itself acts as an IT visionary by supporting IT solutions as a mean to enable the business. The IT organisation can influence these decisions controlled by the business by providing extensive information for strategic decisions that will allow the business to respond to customer demand faster than competitors will.

New technologies are needed and innovative ways in working to answer demand, and technologies are providing the tools to do so. 'The business expects IT to find

new innovative solutions and act as an architect to implement these innovations' (IT architect). This asks for an IT organisation that can maintain interesting connections with innovative partners to keep answering customer demand and gain technology leadership over others. To integrate these special solutions there's a need for a strict but reasonable architecture group, stressing the importance of a generic architecture.

\subsection{Validation of the strategic execution perspective on IT governance}

The strategic execution perspective expects IT to be supportive to the business at the lowest possible cost and not to interfere with the business on a strategic level. The business decides on the role of IT in the organisation, enterprise wide standardisation, business requirements for business applications and IT investments. IT only decides on the IT infrastructure.

\subsubsection{Interview results}

The focus is on lowering the overall cost of IT, making IT as cheap as possible. IT is not viewed upon as a strategic asset in the organisation and an organisation should therefore 'Manage IT like a business, and consider it as a cost centre on which cut backs should 
Maur, W. in der, Walbeek, W. van, Batenburg, R. A framework for integrating IT governance and business/lF alignment principles. International Journal of Business Innovation and Research: 2009, 3(5), 555-573

apply when necessary' (CEO). IT is not considered as a strategic asset but primarily as supportive. IT is a commodity when there is no need for innovation to answer demand that is more complex.

The business stops using IT as a strategic asset and start managing it like a business as soon as it is not needed to offer new solutions. IT is just like any other process, and has to be managed on cost 'The business wants to approve every investment IT makes' (CEO). To stay aligned with the business in such a situation, IT implements the requested solutions or has it implemented at the lowest cost by other parties: "The IT organisation sees to it that costs are low, controllable and justifiable to the business. Leaving a small IT organisation that works on a 'ask and we'll deliver' and 'keep the lights on' basis, while concentrating on lowering costs" (IT architect).

'Have IT make what the organisation needs at the lowest costs and it has to focus on just that!' (CEO) according to a respondent which illustrates that the business sets out the business strategy to make sure that IT is observed in business terms. Which links with the role of the business: strategy formulator, the business strategy then changes certain business processes and finally the IT organisation.

\section{CONCLUSION AND DISCUSSION}

We departed this article with a condensed analysis of the literature on business/IT alignment, in particular applied on the financial sector. Based on this, we developed a framework that combines the IT governance model of Weill and Ross (2004) with the strategic alignment principles defined by Henderson and Venkatraman (1993), to fill the gap between these two concepts. This resulted into a framework to specify how business/IT alignment in organisations actually can be achieved. The framework defines an allocation scheme for allocating strategic IT decisions between the business and IT domain, and can therefore be considered as method for mobilising innovation as well (cf. Pandya and Anand, 2008).

We argued that retail banks are particularly suited as a sector to validate our framework, given its strong dependency on IS/IT developments and the strategic importance of process performance in this sector (Wagner, 2008). The expert validation of our framework through interviewing representatives from all the main Dutch retail banks and industry organisations can be considered successful. All 12 respondents basically understood and acknowledged the structure and principles of our framework.

The expert validation also showed however, that Dutch retail banks are not allocating the strategic IT decisions (IT principles, IT investments and prioritisation to the IT domain) as conditional as our framework assumed. Contrary to one of our expectations, nearly all experts say that 'the business' in Dutch retail banks is in control over all strategic decisions. This is contrary to the SAM by Henderson and Venkatraman, who claim that IT should make strategic decisions to optimally profit from IT functionalities. The experts also stated that Dutch retail banks (in general) prioritise the business strategy. So in the case of what is labelled 'strategic execution', 'technology potential', and the 'competitive potential' perspective, the majority of the respondents stated that the business will not allow the IT strategy to run IT decisions. In this respect the retail banks appeared to maintain a direct and traditional control over innovation through IT (cf. Czuchry and Yasin, 2007).

The fact that the Dutch retail banks do not fully apply the perspectives and its IT decision allocations is most probably related to other contextual forces surrounding the process of achieving alignment. One reason for this result might be in the fact that retail banks are relatively unsatisfied with their IT performance so far. The financial market is strictly regulated and new regulations come and go (SoX, BASEL I and II; cf. Wagner, 2008). This causes IT to spend a lot of time and money in implementing (apparently non-value adding) projects to ensure the Dutch retail banks remain compliant with governmental regulations. The business has therefore low expectations with regard to their investments in IT, as these activities do not directly supply competitive advantage. This can lead to divesting in IT, making it even more difficult for IT to spend time on finding new value adding solutions. Thus becoming aligned is not solely a case of profiting from the opportunities, but also managing contingencies.

\subsection{Suggestions for further research}

We suggest that the applicability of our framework can be extended and adapted to other industries as well. Above all, IT governance - as a management tool to help organise IT - is not solely a retail bank matter. Other industries that are strongly information dependent and therefore rely on IT in their daily processes, can therefore profit from a structured tool on how to achieve alignment. Possible industries are insurance industries (damage in kind and pension funds), logistic industries and fast moving consumer goods industries. 
Maur, W. in der, Walbeek, W. van, Batenburg, R. A framework for integrating IT governance and business/lF alignment principles. International Journal of Business Innovation and Research: 2009, 3(5), 555-573

Another clear limitation of our expert validation is that it applied to the Dutch financial sector. Applicability of our framework and validation tools in other countries will result in interesting opportunities for cross-national comparison.

\section{ACKNOWLEDGEMENT}

The authors would like to thank the anonymous reviewers for their encouraging and constructive comments.

\section{REFERENCES}

Baets, W.J. (1996) 'Some Empirical Evidence on is Strategy. Alignment in Banking', Information and Management, Vol. 30, pp.155-177.

Barua, A., Kriebel, C.H. and Mukhopadhyay, T. (1991) 'An economic analysis of strategic information technology investments', MIS Quarterly, Vol. 15, pp.313-331.

Batenburg, R. and Versendaal,J. (2008) 'Business/lT-alignment for customer relationship management: framework and case studies', Int. J. electronic Customer Relationship

Management, Vol. 1, pp.258-268 Beccalli, E. (2007) 'Does IT investment improve bank performance? Evidence from Europe', Journal of Banking and Finance, Special Issue on Developments in European Banking, Vol. 31, pp.2205-2230.

Bergeron, F., Raymond, L. and Rivard, S. (2004) 'Ideal patterns of strategic alignment and business performance', Information and Management, Vol. 41, pp.1003-1020.

Beukers, M., Versendaal, J., Batenburg, R. and Brinkkemper, S. (2006) 'The procurement alignment framework: construction and application', Wirtschaftsinformatik, Vol. 48, pp.323-330 Brand, K.B.H. (2007) IT Governance based on Cobit 4.0 - A Management Guide. Van Haren Publishing.

Broadbent, M. and Weill, P. (1993) 'Improving business and information strategy alignment: learning from the banking industry', IBM Systems Journal, Vol. 32, pp.162-179.

Broadbent, M. and Weill, P. (1997) 'Management by maxim: how business and IT managers can create IT infrastructures', Sloan Management Review, Vol. 38, pp.77-92.

Broadbent, M. and Kitzis, E. (2005) 'Interweaving business-driven IT strategy and execution: four foundation factors', Ivey Business Journal, Vol. 69, pp.1-6.

Byrd, T.A., Lewis, B.R. and Bryan, R.W. (2006) 'The leveraging influence of strategic alignment on IT investment: an empirical examination', Information and Management, Vol. 43, pp.308-321.

Carr, N. (2003) 'IT doesn't matter', Harvard Business Review, Vol. 81, pp.41-49.

Chan, Y.E. (2002) 'Why haven't we mastered alignment? The importance of the informal organization structure', MIS Quarterly Executive, Vol. 1, pp.97-112.

Chan, Y. and Reich, H. (2007) 'IT alignment: what have we learned?', Journal of Information Technology, Vol. 22, pp.297-315.

Chan, Y.E., Sabherwal, R. and Thatcher, J.B. (2006) 'Antecedents and outcomes of strategic IS alignment: an empirical investigation', IEEE Transactions on Engineering Management, Vol. 53, pp.27-47.

Choe, J. (2003) 'The effect of environmental uncertainty and strategic applications of is on a firm's performance', Information \& Management, Vol. 40, pp.257-268.

Coleman, P. and Papp, R. (2006) 'Strategic alignment: analysis of perspectives', Proceedings of the

2006 Southern Association for Information Systems Conference March 11-12, Jacksonville, Florida USA, pp.241-250.

Czuchry, A.J. and Yasin, M.M. (2007) 'Effective marketing of technical innovation', International Journal of Business Innovation and Research, Vol. 1, pp.448-463 Davenport, T.H., Hammer, M. and Metsisto, T.J. (1989) 'How executives can shape their company's information system', Harvard Business Review, March-April, pp.130-134.

De Haes, S. and Van Grembergen, W. (2005) 'IT governance structures, processes and relational mechanisms: achieving IT/business alignment in a major Belgian financial group', Proceedings of the 38th International Conference on Systems Sciences, Hawaii.

Dutta, S. (1996) 'Linking IT and business strategy: the role and responsibility of senior management', European Management Journal, Vol.14, pp.255-269.

Earl, M.J. (1993) 'Experiences in information systems strategic planning', MIS Quarterly, pp.1-24.

Faltermayer, E. (1994) 'Competitiveness: how US companies stack up now', Fortune, Vol. 129, pp.52-64.

Floyd, S.W. and Woolridge, B. (1990) 'Path analysis of the relationship between competitive strategy, information technology, and financial performance', Journal of Management

Information Systems, Vol. 7, pp.47-64.

González-Benito, J. (2007) 'A theory of purchasing's contribution to business performance', Journal of Operations Management, Vol. 25, pp.901-917 Gupta, Y.P., Karimi, J. and Somers, T.M. (1997) 
Maur, W. in der, Walbeek, W. van, Batenburg, R. A framework for integrating IT governance and business/lF alignment principles. International Journal of Business Innovation and Research: 2009, 3(5), 555-573

'Alignment of a firm's competitive strategy and information technology management sophistication: the missing link', IEEE Transactions on

Engineering Management, Vol. 44, pp.399-413.

Henderson, J.C. and Venkatraman, N. (1993) 'Strategic alignment: leveraging information technology for transforming organizations', IBM Systems Journal, Vol. 32, pp.4-16.

IT Governance Institute (ITGI) (2006) 'IT governance global status report 2006', Available at: www.itgi.org (retrieved 29/04/2008).

Jarvenpaa, S.L. and Ives, B (1990) 'Information technology and corporate strategy: a view from the top', Information Systems Research, Vol. 1, pp.351-75.

Johnston, K.D. and Yetton, P.W. (1996) 'Integrating information technology divisions in a bank merger: fit, compatibility and models of change', Journal of Strategic Information Systems, Vol. 5, pp.189-211.

Kearns, G.S. and Lederer, A.L. (2000) 'The effect of strategic alignment on the use of IS-based resources for competitive advantage', Journal of Strategic Information Systems, Vol. 9, pp.265-293.

Kearns, G.S. and Lederer, A.L. (2001) 'Strategic IT alignment: a model for competitive advantage',

Proceedings of the 22nd ICIS, Barcelona, pp.1-12.

Kearns, G.S. and Sabherwal, R. (2007) 'Strategic alignment between business and information technology: a knowledge-based view of behaviors, outcome, and consequences', Journal of

Management Information Systems, Vol. 23, pp.129-162.

Keen, P. (1991) Shaping the Future. Boston, MA: Harvard Business School Press Kvale, S. (1996) InterViews: An Introduction to Qualitative Research Interviewing. London: Sage.

Luftman, J. (1996) Managing in the Information Age: Practical Applications of the Strategic

Alignment Model. New York, NY: Oxford University Press.

Luftman, J. and Brier, T. (1999) 'Achieving and sustaining business-IT alignment', California

Management Review, Vol. 42, pp.109-122.

Luftman, J. and Kempaiah, R. (2007) 'An update on business-IT alignment: 'a line' has been drawn', MIS Quarterly Executive, Vol. 6, pp.165-177.

Miles, M.B. and Huberman, A.M. (2004). Qualitative Data Analysis (2nd ed.). Thousand Oaks, CA: Sage Publications.

Oh, W. and Pinsonneault, A. (2007) 'On the assessment of the strategic value of information technologies: conceptual and analytical approaches', MIS Quarterly, Vol. 31, pp.239-265.

Pandya, K.V. and Anand, H. (2008) 'Role of innovation in IT in achieving its business objectives: a case study', International Journal of Business Innovation and Research, Vol. 2, pp.289-313.

Papp, R. (1995) Determinants of Strategically Aligned Organizations: A Multi-Industry,

Multi-Perspective Analysis. Hoboken, NJ: Stevens Institute of Technology. Dissertation.

Papp, R (1998) 'Alignment of business and information technology strategy: how and why', Information Management, Vol. 11, pp.6-11.

Papp, R. (1999) 'Business IT alignment: productivity paradox or payoff?', Industrial Management and Data Systems, Vol. 99, pp.367-373.

Pollalis, Y.A. (2003) 'Patterns of co-alignment in information-intensive organizations: business performance through integration strategies', Int. J. Information Management, Vol. 23, pp.469-492.

Porter, M.E. and Miller, V.E. (1985) 'How information gives you competitive advantage', Harvard Business Review, Vol. 63, pp.149-60.

Reich, B.H. and Benbasat, I. (2000) 'Factors that influence the social dimension of alignment between business and information technology objectives', MIS Quarterly, Vol. 24, pp.81-113.

Ross, J.W. (2003a). 'Creating a strategic IT architecture competency: learning in stages', MISQE, Vol. 2, p.31.

Ross, J.W. (2003b) 'Creating a strategic IT architecture competency: learning in stages', MISQ

Executive, Vol. 2, p.43.

Ross, J.W. and Beath, C.M. (2002) 'Beyond the business case: new approaches to IT investment', MIT Sloan Management Review, Vol. 43, pp.51-59.

Smith, A.D. (2009) 'Customer relationship management: a look at incentive programmes and their usefulness in selected service firms', Int. J. Business Innovation and Research, Vol. 3, pp.1-16 Solow, R.M. (1987) 'We'd better watch out', New York Times Book Review, Vol. 12, July, p.36.

Sledgianowski, D. and Luftman, J. (2005) 'IT-business strategic alignment maturity: a case study', Journal of Cases on Information Technology, Vol. 7, pp.102-120.

Van Grembergen, W. (2000) 'The balanced scurecced and IT governance, Information Systems Control Journal, Vol, 22, pp.40-43.

Van Grembergen, W. and de Haes, S. (2004) IT Governance Mechanismen: COBIT en de Balanced Scorecard's Growenhage, Kluwer. 
Maur, W. in der, Walbeek, W. van, Batenburg, R. A framework for integrating IT governance and business/lif alignment principles. International Journal of Business Innovation and Research: 2009, 3(5), 555-573

Wagner, H-T. (2008) 'IT business alignment and process performance: results from a survey in the finance industry', Proceedings of the 16th European Conference on Information Systems, National University of Ireland, Galway, Ireland.

Wagner, H-T. and Weitzel, T. (2006) 'Operational IT business alignment as the missing link from IT strategy to firm success', 12th Americas Conference on Information Systems (AMCIS

2006), Acapulco, Mexico.

Weill, P. (2004) 'Don't just lead, govern: how top-performing firms govern IT', MIS Quarterly

Executive, Vol. 3, pp.1-17 Weill, P. and Ross, J.W. (2004) IT Governance: How Top Performers Manage IT Decision Rights

for Superior Results. Boston, MA: Harvard Business School Press.

Weill, P., Subramani, M. and Broadbent, M. (2002) 'Building IT infrastructure for strategic agility', MIT Sloan Management Review, Vol. 44, pp.57-65.

Wilson, T.D. (1989) 'The implementation of information system strategies in UK companies: aims and barriers to success', Int. J. Information Management, Vol. 9, pp.245-258.

Yin, R.K. (2002) Case Study Research. Design and Methods. California: Sage Publications.

\section{FIGURES AND TABLES}

Figure 1 The strategic alignment perspectives (Henderson and Venkatraman, 1993) (see online version for colours)

Functional integration

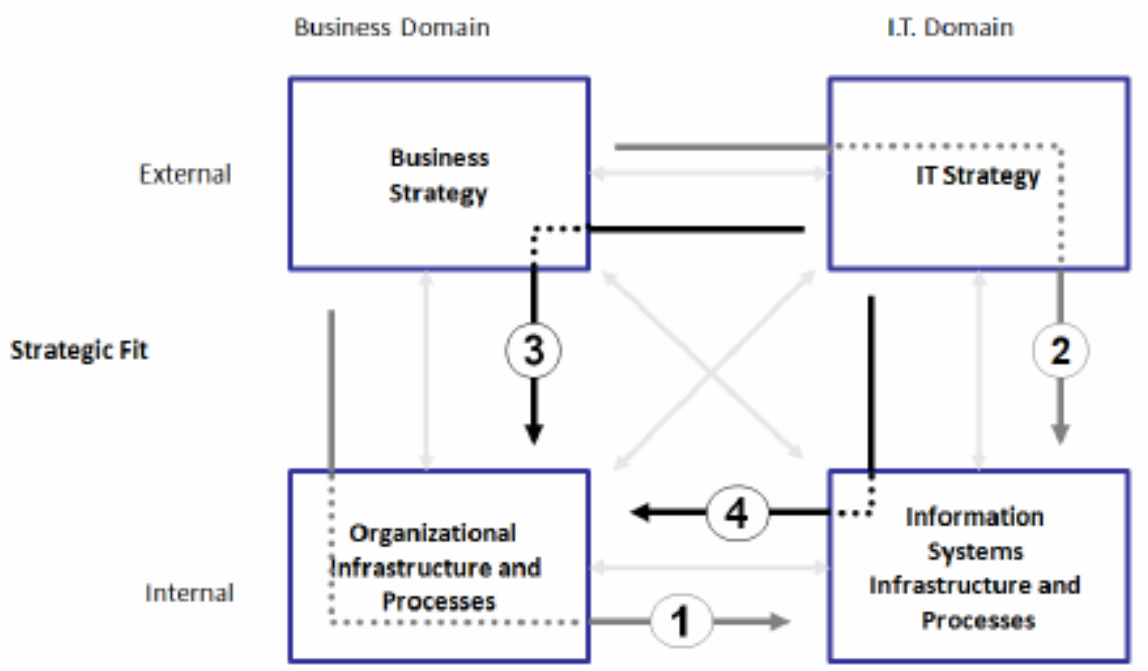


Table 1 The five IT decisions (Weill and Ross, 2004)

\begin{tabular}{|c|c|c|}
\hline Decision & Description & References \\
\hline IT principles & $\begin{array}{l}\text { High level statements on how IT is to be used in the firm. } \\
\text { They capture the very essence of an organisation future } \\
\text { direction and how IT is used to reach that future }\end{array}$ & $\begin{array}{l}\text { (cf. Davenport, } \\
\text { Hammer and } \\
\text { Metsisto, 1989; } \\
\text { Broadbent and } \\
\text { Weill, 1997) }\end{array}$ \\
\hline IT architecture & $\begin{array}{l}\text { Describes an integrated set of technical choices to guide } \\
\text { the organisation in satisfying business needs. The } \\
\text { architecture functions as a policy and rule giver that govern } \\
\text { the use of IT and how business will be done through IT. It } \\
\text { includes standards and guidelines for technology, data-use, } \\
\text { application design and management of change to exploit } \\
\text { new technologies }\end{array}$ & (cf. Ross, 2003a,b) \\
\hline $\begin{array}{l}\text { IT } \\
\text { infrastructure }\end{array}$ & $\begin{array}{l}\text { Is a description on how to build the IT foundation for the } \\
\text { business organisation. IT infrastructure consists of the } \\
\text { shared and standard IT services that are centrally } \\
\text { coordinated (CRM, ERP systems, etc.). Infrastructure also } \\
\text { covers the decisions about the IT infrastructure strategy } \\
\text { when we need to define requirements for infrastructure } \\
\text { capability as well as their location (centralised, } \\
\text { decentralised, etc.). } \\
\text { The infrastructure is critical when considering the speed } \\
\text { with which new business initiatives can be implemented }\end{array}$ & $\begin{array}{l}\text { (cf. Keen, 1991; } \\
\text { Weill, Subramani } \\
\text { and Broadbent, } \\
\text { 2002) }\end{array}$ \\
\hline $\begin{array}{l}\text { Business } \\
\text { applications } \\
\text { needs }\end{array}$ & $\begin{array}{l}\text { The identification and specification of business needs for } \\
\text { purchased or internally developed IT applications. This } \\
\text { decision has two conflicting objectives, creativity and } \\
\text { discipline. Creativity is about identifying new and more } \\
\text { effective ways to deliver customer value using IT. } \\
\text { Discipline is about architectural integrity, ensuring } \\
\text { application leverage and architectural advantages }\end{array}$ & (cf. Earl, 1993) \\
\hline $\begin{array}{l}\text { IT investment } \\
\text { and } \\
\text { prioritisation }\end{array}$ & $\begin{array}{l}\text { The IT investment decision is about the investment of IT } \\
\text { resources, including prioritisation and focus. Also } \\
\text { describes the procedures for IT project handling }\end{array}$ & $\begin{array}{l}\text { (cf. Ross and } \\
\text { Beath, 2002) }\end{array}$ \\
\hline
\end{tabular}


Maur, W. in der, Walbeek, W. van, Batenburg, R. A framework for integrating IT governance and business/lF alignment principles. International Journal of Business Innovation and Research: 2009, 3(5), 555-573

Figure 2 Integration of strategic alignment and IT governance into one framework. (see online version for colours)

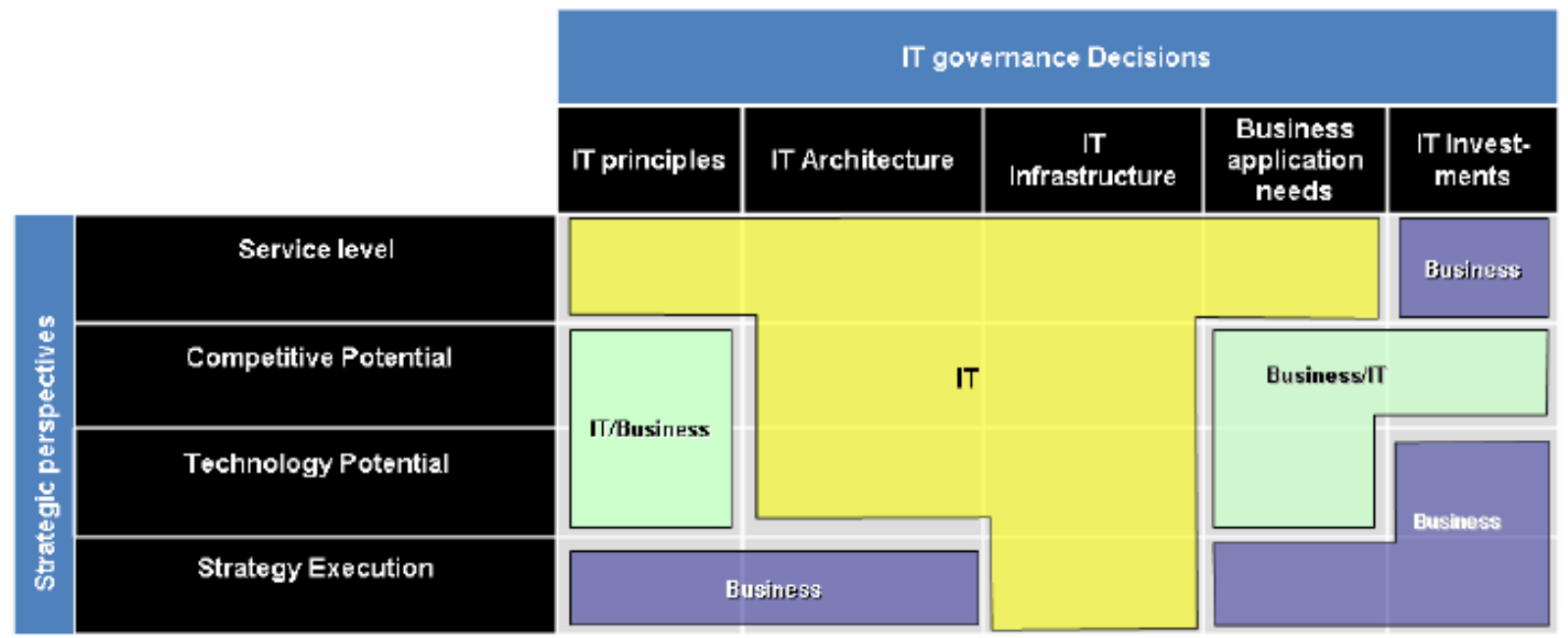

Table 2 Overview of respondents

\begin{tabular}{llll}
\hline Interviewee \# & Organisation & Position/function & Date of interview \\
\hline 1 & Boober & Chief Executive Officer & Oct 2007 \\
2 & Finnion & Chief Executive Officer & Oct 2007 \\
3 & Second Floor & Chief Executive Officer & Oct 2007 \\
4 & ABN AMRO bank & Manager Financial Solutions & Oct 2007 \\
5 & Probanco/Fortis & Partner/Interim manager (@ Fortis) & Oct 2007 \\
6 & Rabobank & IT Architect & Nov 2007 \\
7 & ING Bank & IT Architect & Nov 2007 \\
8 & ING Group & IT Benchmarker and Member IT & Nov 2007 \\
9 & Postbank & Governance Workgroup Netherlands & \\
10 & Nationale Nederlanden & IT Architect and Chairman SOA & Nov 2007 \\
& & Workgroup Netherlands 2007 \\
11 & Rabobank Retail & Business/IT Architect & Dec 2007 \\
12 & ING Group & Member CTO office & Dec 2007 \\
\hline
\end{tabular}

